\title{
Integracja ukraińskich studentów podejmujących naukę w Polsce
}

Artykuł prezentuje wyniki badań nad imigracją ukraińskich studentów do Polski. Badania zostały zrealizowane metodą sondażową za pomocą ankiety audytoryjnej wśród studentów w 2015 i 2017 r. Próba badawcza liczyła 606 studentów. Badania realizowano w Krakowie, Rzeszowie i Przemyślu. Wynika z nich, że głównym motywem przyjazdu na studia do Polski była chęć uzyskania zagranicznego wykształcenia, mającego zwiększyć szanse życiowe młodzieży. Największym problemem, jaki się pojawił po przyjeździe, były wysokie koszty życia w Polsce oraz brak znajomości języka i niedostateczna integracja z polskimi rówieśnikami. Najwyżej studenci ocenili infrastrukturę techniczną i cyfrową polskich uczelni oraz serdeczne i życzliwe stosunki z pracownikami uczelni. Znaczącym problemem dla studentów był brak możliwości znalezienia odpowiedniej pracy w czasie studiów i po ich skończeniu. Większość studentów po licencjacie planuje zdobyć wykształcenie magisterskie. Po zakończeniu edukacji tylko 13\% ankietowanych zamierza wrócić na Ukrainę. Ponad połowa chce pozostać w Polsce, a 1/3 wyjechać dalej na zachód.

Słowa kluczowe: migracje edukacyjne, studenci zagraniczni, ukraińscy studenci w Polsce

\section{Integration of ukrainian students in Poland}

The article presents the results of research on the immigration of Ukrainian students to Poland. The research was conducted in 2015 and 2017 among students with the use of the survey method and the auditorium questionnaire technique. The research sample consisted of 606 students and was conducted in Kraków, Rzeszów and Przemyśl. The main motivation for going to Poland was the will to get an education abroad, which is supposed to increase one's life chances. The biggest problems the students had to face after arriving in Poland were high costs of living, insufficient command of Polish and incomplete integration with Polish peers. The students

\footnotetext{
${ }^{1}$ Kontakt: piotr.dlugosz@up.krakow.pl
} 
evaluated the technical and digital infrastructure of Polish universities and the rapport with academic staff highly. The main problem for the students was the difficulty of finding appropriate jobs during their studies and after finishing. The majority of students plan to continue studying second cycle degree programs after finishing their first cycle studies. Only 13\% of students declare that they will return to Ukraine after graduating. More than half want to stay in Poland whereas one third want to go to the West for economic reasons.

Keywords: Educational migration, foreign students, Ukrainian students in Poland

\section{Uwagi wstępne}

W dobie globalizacji migracja staje się powszechna. Rosnąca liczba emigrantów edukacyjnych, internalizacja szkolnictwa wyższego, edukacyjna mobilność stanowią przejawy megatrendu XXI wieku². Mobilność wynikająca z poszukiwania pracy, bezpieczeństwa, odpowiedniej jakości życia oraz edukacji stanowi odpowiedź na wyzwania nowoczesności. W społeczeństwie wiedzy ${ }^{3}$, społeczeństwie ryzyka jednostka jest coraz bardziej świadoma wpływu wykształcenia na jej pozycję zawodową i społeczną ${ }^{4}$ W społeczeństwie kredencjalnym walutę wymienialną na statusy społeczne stanowi dyplom wyższej uczelni. Jednocześnie w warunkach umasowienia wyższej edukacji dochodzi do inflacji wykształcenia ${ }^{5}$.

Konsekwencją tego zjawiska jest rywalizacja w dostępie do prestiżowych uczelni. Część młodzieży, zazwyczaj ta z wyższym statusem, wybiera uczelnie zagraniczne cieszące się wyższym prestiżem i wysoką jakością nauczania ${ }^{6}$.

W globalnej wiosce dostęp do studiów zagranicznych staje się coraz łatwiejszy. Według statystyk OECD w latach 70 . XX w. na świecie liczba zagranicznych studentów wynosiła 0,8 mln, a w 2015 r. - 4,6 mln. Największy udział studentów z zagranicy w stosunku do studentów krajowych odnotowano w Luxemburgu (46\%), Nowej Zelandii (21\%), Wielkiej Brytanii (19\%), Szwajcarii (17\%), Australii (16\%), Austrii (16\%), Belgii (11\%), Holandii (11\%). Polska na tle liderów umiędzynarodowienia edukacji wyższej zajmuje niską pozycję (3\%) ${ }^{7}$. Jednakże w ostatnich latach również na polskich uczelniach zauważono dynamiczny wzrost liczby

2 Zob. M. Pietraś (2017), Umiędzynarodowienie szkolnictwa wyższego w Polsce, w: Domański T., Stępień-Kuczyńska A., Włodarska-Frykowska A. (red.), Internacjonalizacja polskich ośrodków politologicznych, Łódź: Wydawnictwo Uniwersytetu Łódzkiego, ss. 81-95.

3 Zob. P.F. Drucker (1999), Społeczeństwo prokapitalistyczne, przeł. G. Kranas, Warszawa: Wydawnictwo Naukowe PWN.

${ }^{4}$ Zob. U Beck (2002), Społeczeństwo ryzyka, przeł. S. Cieśla, Warszawa: Scholar.

${ }^{5}$ Zob. R. Collins (1979), The Credential Society, New York: Academic Press.

${ }^{6}$ Zob. A.M. Findlay, R. King, F.M. Smith, A. Geddes \& R. Skeldon (2012), World class? An investigation of globalisation, difference and international student mobility, „Transactions of the Institute of British Geographers", Vol. 37, Issue 1, pp. 118-131.

${ }^{7}$ Education at a Glance 2017, (2017), p. 300, http://www.oecd.org/edu/education-at-a-glance19991487.htm, dostęp: 12.11.2017. 
cudzoziemców. Współczynnik internalizacji studiów w Polsce w 2006 r. wynosił 0,52\%, a w 2016 r. wzrósł do 5,15\% ${ }^{8}$.

Do znacznej poprawy wskaźników umiędzynarodowienia polskich uczelni przyczynili się studenci z Ukrainy. W latach 2006-2016 nastąpił ich szesnastokrotny przyrost w Polsce. W 2006 r. były to 2223 osoby, a dziesięć lat później liczba ukraińskich studentów wynosiła już 35 584. W roku akademickim 2016/17 ponad połowę cudzoziemców studiujących na polskich uczelniach stanowili Ukraińcy $(66,2 \%)^{9}$. W związku z dużym napływem ukraińskich studentów do Polski zaczęto mówić o ukrainizacji polskich uczelni ${ }^{10}$.

$\mathrm{O}$ ile znane są ogólne trendy dotyczące emigracji edukacyjnych do Polski ukraińskich studentów, o tyle brakuje wyjaśnienia powstania tego fenomenu. Prezentowany artykuł ma na celu odpowiedzieć na pytanie dotyczące mechanizmów imigracji ukraińskich studentów do Polski w ostatnich latach. Przyjęto hipotezę, że strumień imigracji edukacyjnej jest regulowany mechanizmem czynników wypychających młodzież z Ukrainy i czynników przyciągających do podjęcia studiów w Polsce. Mówiąc najogólniej pogarszająca się ocena sytuacji społeczno-politycznej na Ukrainie oraz spodziewane korzyści po skończeniu studiów na polskich uczelniach stanowią główny mechanizm odpowiedzialny za imigrację do Polski ukraińskich studentów. Weryfikacja hipotezy zostanie przeprowadzona w oparciu o wyniki badań sondażowych realizowanych w latach 2015 i 2016 wśród studentów ukraińskich studiujących w Polsce.

\section{Przegląd literatury}

Problem emigracji edukacyjnych ma długą tradycję. Od wielu lat znajduje się $\mathrm{w}$ centrum zainteresowania badaczy ${ }^{11}$. W Polsce zjawisko to pojawiło się $\mathrm{w}$ latach 50. XX w. wraz z uruchomieniem programów edukacyjnych dla biednych

${ }^{8}$ Zob. W. Siwiński (2017), Autostrada edukacyjna Polska-Ukraina - projekt w budowie 2017, upc.kpi.ua/documents/dni_nauky/presentations/06-04-2017/Siwinski.pdf, dostęp: 10.10.2017.

${ }^{9}$ Szkoły wyższe i ich finanse w 2016 r. (2017), Warszawa, s. 35, http://stat.gov.pl/obszary-tematyczne/edukacja/edukacja/szkoly-wyzsze-i-ich-finanse-w-2016-r-,2,13.html, dostęp: 20.10.2017.

${ }_{10}$ Zob. Studenci zagraniczni w Polsce w 2015, (2015), Warszawa, http://www.studyinpoland.pl/ konsorcjum/index.php?option=com_content\&view=article\&id=6922:raport-qstudenci-zagraniczniw-polsce-2015\&catid=220:115-newsletter-2015\&Itemid=100143, dostęp: 22.10.2017].

${ }^{11}$ Zob. R. Rickett (1991), International Student Mobility, „Higher Education in Europe”, Vol. 2, Issue 4 -5, pp. 37-40; T. Mazzarol, N.G. Soutar (2002), „Push-pull” factors influencing international student destination choice, „International Journal of Educational Management”, Vol. 16, Issue 2, pp. 82-90; L. Verbik, V. Lasanowski (2007), International student mobility: Patterns and trends, The Observatory on Borderless Higher Education Woburn House, London, http://www.obhe.ac.uk/documents/view_details?id=14, dostęp: 5.11.2017; K. Guruz (2011), Higher education and international student mobility in the global knowledge economy, New York: State University of New York Press; R. Bhandari, P. Blumenthal (eds.) (2010), International students and global mobility in higher educa- 
państw z obszarów tzw. Trzeciego Świata ${ }^{12}$. Studenci ze Wschodu, czyli państw byłego Związku Radzieckiego zaczęli napływać na początku lat 90. XX w. Wtedy to głównie na studia do Polski przyjeżdżała młodzież z polskimi korzeniami, korzystająca $z$ oferty stypendialnej ${ }^{13}$. Dzisiaj sytuacja uległa zmianie. Po pierwsze, studenci zagraniczni polskiego pochodzenia są na polskich uczelniach w zdecydowanej mniejszości. W 2016 r. studiowało ich 7675 osób (w tym z Ukrainy 3520). Ogólna liczba studentów obcokrajowców wynosiła 65793 (w tym z Ukrainy 35 584) ${ }^{14}$. Po drugie, Polska stała się najpopularniejszym krajem docelowym emigracji edukacyjnej wśród ukraińskiej młodzieży. Udział studentów z Ukrainy w stosunku do liczby studentów zagranicznych był najwyższy w Polsce (53\%). Dla porównania w Czechach było to 6\%, na Słowacji 7\%, w Niemczech 3\%, w Rosji 7\% ${ }^{15}$.

Problematyka emigracji ukraińskich studentów do Polski spotyka się w ostatnich latach $z$ dużym zainteresowaniem badaczy po obu stronach granicy ${ }^{16}$. W prowadzonych badaniach często pojawia się kwestia uwarunkowań emigracji edukacyjnych ukraińskich studentów do Polski. Autorzy starają się odkryć mechanizmy odpowiedzialne za powstanie tego zjawiska. $Z$ analiz dotychczasowych badań wyłania się kilka głównych czynników mających wpływ na obserwowany fenomen.

tion: National trends and new directions, New York: Palgrave Macmillan US; R. Choudaha, L. Chang (2012), Trends in international student mobility, „World Education News \& Reviews”, Vol. 25, Issue 2, pp. 1-5; R. Choudaha (2017), Three waves of international student mobility (1999-2020), „Studies in Higher Education", Vol. 42, Issue 5, pp. 825-832.

${ }_{12}$ C. Żołędowski (2010), Studenci zagraniczni w Polsce, Warszawa: Wydawnictwo UW, s. 54.

${ }_{13}$ Ibidem, s. 55.

${ }^{14}$ Szkoły wyższe i ich finanse w 2016 r..., s. 34.

15 О. Слободян, Є. Стадний (2016), Українськ студенти за кордоном, CEDOS, https://cedos. org.ua/uk/osvita/ukrainski-studenty-za-kordonom-skilky-ta-chomu, dostęp: 10.10.2017.

${ }^{16}$ Zob. C. Żołędowski, Studenci zagraniczni ....; O. Bilyakovska (2011), Ukrainian Student Migration to Poland, „Humanites \& Social Sciences”, pp. 292-293; L. Semiv, Y. Hvozdovych (2012), The intellectual migration of the youth in Ukraine: the backgrounds for „,brain circulation”, „Journal of International Studies", Vol. 5, Issue 2, pp. 72-81; P. Długosz (2015), Zjawisko edukacji transgranicznej na przykładzie ukraińskich studentów na Podkarpaciu, „Youth Policy: Problems and Prospects”, Vol. 6, ss. 161-168; Є. Стадний (2015), Українські студенти в польських ВНЗ (2008-2015), CEDOS, https://cedos.org.ua/uk/osvita/ukrainski-studenty-v-polskykh-vnz-2008-2015, dostęp: 11.10.2017; О. Слободян, Є. Стадний (2016), Українськ студенти...; K. Gomółka (2015), Students from Ukraine, Belarus and Moldova at Polish universities, „Annales Universitatis Mariae Curie-Skłodowska, sectio K Politologia”, Vol. 22, Issue. 1, ss. 213-225; S. Kapera (2017), Motywy wyboru i oczekiwania studentów z Ukrainy wobec kształcenia na kierunkach związanych z turystyka, ,Turyzm”, Vol. 27, Issue.1, ss. 19-23; D. Izdebska-Długosz, Dlaczego Polska? Motywy wyboru studiów w Polsce u młodzieży ukraińskiej perspektywa porównawcza, w: Kordoński R., Kordońska O., Muszyński Ł. (red.), Doświadczenia oraz perspektywy strategicznego partnerstwa, Lwów-Olsztyn: Wydawnictwo Uniwersytetu Lwowskiego 2017, ss. 63-75; M. Pakosz (2017), Rekrutacja kandydatów z Ukrainy na studia wyższe w Polsce. Perspektywa dla polskich uczelni, w: Siwińska B., Mazurek G. (red.), Czas internalizacji II, Warszawa: Elipsa, ss. 202-218; V. Cherba, H. Tobol, D. Mushkatiorova (2017), The Reasons of Educational Migrations of Ukrainian Students Abroad, „Інвестиціï: практика та досвід”, Vol.12, Issue 1, pp. 68 -72.

Zob. A. Stasik (2017), Raport z badania ankietowego „Zagraniczni studenci 2015/16”, https:// nawa.gov.pl/nawa/raporty-i-analizy, dostęp: 22.11.2017. 
Polska jest dla Ukraińców relatywnie tanim krajem pod względem kosztów utrzymania i wysokości czesnego. Według wyliczeń, miesięczne koszty utrzymania wynosiły w 2012 r. w Polsce 208 euro, we Włoszech 416 euro, w Austrii 450 euro, w Hiszpanii 532 euro, we Francji 615 euro, w Niemczech 680 euro. Istotne jest również to, że w Polsce student może pracować bez ograniczeń, a na Zachodzie istnieją limity ograniczające pracę studentów. Absolwent polskiej uczelni również może pracować bez zezwolenia ${ }^{17}$.

Ponadto dzięki stypendiom, różnym ulgom, zwolnieniom z czesnego i materialnej pomocy studia dla Ukraińców mogą być tańsze ${ }^{18}$. $Z$ danych wynika, iż $38 \%$ ukraińskich studentów było zwolnionych $\mathrm{z}$ opłat za nauczanie ${ }^{19}$. Niektórzy badacze twierdzą, że studia zagranicą są tańsze od tych na Ukrainie ${ }^{20}$. Przykładowo za rok studiów w Polsce trzeba zapłacić w państwowej uczelni 1800-2500 euro. W Niemczech jest zdecydowanie drożej: na państwowych uczelniach czesne wynosi 400-3300 euro, a na prywatnych 10 000-42 000 euro. Dla porównania, na Ukrainie opłata za czesne w państwowej uczelni wynosi 130-1500 euro, a na prywatnej 170-1200 euro ${ }^{21}$. Studenci ukraińscy w Polsce sami też potwierdzają, że studia są u nas tanie ${ }^{22}$. Warto też zaznaczyć, że od $2015 \mathrm{r}$. zostały uwolnione ceny za studia dla obcokrajowców na państwowych uczelniach, przez co stały się one konkurencyjne w stosunku do prywatnych uczelni, na których do tej pory studiowała większość studentów z Ukrainy ${ }^{23}$.

Innym czynnikiem podwyższającym koszty studiów na ukraińskich uczelniach jest korupcja ${ }^{24}$. Jej występowanie sprawia, że młodzież z pobudek materialnych i moralnych częściej może podejmować decyzję o wyborze studiów w Polsce ${ }^{25}$.

${ }^{17}$ C. Żołędowski, Studenci zagraniczni w Polsce..., s. 45.; O. Bilyakovska, Ukrainian Student Migration to Poland..., s. 293; О. Слободян, Є. Стадний, Украӥнськ студенти за кордоном...

18 Л. М. Бондарук, Л. М. Щерба (2017), Роль міжкультурної освіти у процесі інтеграціі України в європейський простір, „Педагогічний пошук”, Vol. 94, Issue 2, с. 34.

${ }_{19}$ O. Bilyakovska, Ukrainian Student Migration to Poland..., p. 293.

${ }^{20}$ V. Cherba, H. Tobol, D. Mushkatiorova, The Reasons of Educational..., p. 71.

${ }^{21}$ Ibidem.

22 D. Izdebska-Długosz, Dlaczego Polska?..., s. 70.

${ }_{23}$ Zob. M. Pakosz, Rekrutacja kandydatów..., s. 208; Є. Стадний, Украйнські студенти в польських ВНЗ...

${ }^{24}$ Zob. Є. Стадний, Украӥнські студенти в польських ВНЗ...; E. Inglot-Brzęk, M. Stopa (2015), Nowe konteksty "starych" pograniczy. Przypadki ukraińskich studentów w rzeszowskiej uczelni; w: Chudzik A. (red.), Na pograniczach. Kulturowe obrazy ludzi i miejsc, Sanok: PWSZ, s. 238; P. Długosz, Zjawisko edukacji transgranicznej..., s. 165; J. Bierówka (2016), Opinie studentów ukraińskich na temat ich integracji akademickiej, „Państwo i Społeczeństwo”, Vol. 16, Issue 1, s. 205; D. Izdebska-Długosz, Dlaczego Polska?..., s. 68; К. Зарембо (2017), Молодь України 2017, с. 76. http://neweurope.org.ua/analytics/ukrayinske-pokolinnya-z-tsinnosti-ta-oriyentyry, dostęp: 22.11.2017.

${ }^{25}$ Z badań zrealizowanych na Ukrainie we wrześniu 2017 r. do dania łapówek w służbie zdrowia przyznało się $51 \%$, do wręczenie łapówki w szkole wyższej $24 \%$. Корупиія у повсякденному житті українців: За щзо даємо хабарі? Кому і чому? http://dif.org.ua/article/koruptsiya-u-povsyakdennomu-zhitti-ukraintsiv-za-shcho-daemo-khabari-komu-i-chomu345654, dostęp: 25.11.2017. 
Najnowsze badania wśród ukraińskiej młodzieży pokazują, że 62\% stwierdza, iż na ukraińskich uczelniach wyższych można kupować oceny ${ }^{26}$.

Bliskość kulturowa i językowa stanowi kolejny istotny czynnik wpływający na wybór Polski jako miejsca docelowego emigracji edukacyjnej ${ }^{27}$. Podobieństwo kultury ukraińskiej i polskiej sprawia, że lęk przed wyjazdem i adaptacją jest niewielki. Bliskość kulturowa Polski wzmacnia u młodych Ukraińców poczucie bezpieczeństwa i swojskości. Dominika Izdebska-Długosz pisze, że „podobieństwo języka i kultur wzmacnia efekt bycia u siebie. Ukraińcy nie dążą do więc do ekstremalnych doznań związanych z poznaniem obcych, egzotycznych krajów i kultur. Wręcz przeciwnie: szukają namiastki Ukrainy, tam gdzie jest bezpieczniej i gdzie pewniej o chleb”28. Wyniki analizy regresji również wskazują, iż najważniejszym czynnikiem mającym wpływ na wybór kraju emigracji są niskie koszty psychiczne, jakie trzeba będzie ponieść w związku z przeprowadzką do innego kraju²9.

Z bliskością Polski dla Ukraińców łączy się też wielkość ukraińskiej diaspory w Polsce. Dzięki dużej liczbie pracujących w Polsce rodaków, młodzież ukraińska czuje się bezpieczniej, przyjeżdżając tutaj. Szacuje się, że w Polsce przebywa około milion obywateli Ukrainy ${ }^{30}$. Często też pracujący rodzice ściągają swoje dzieci na studia do Polski. Młodzież wybierająca się na studia do Polski korzysta $\mathrm{z}$ sieci swoich znajomych i rodziny, przez co problemy adaptacyjne łatwiej jest rozwiązywać. Twierdzi się też, że migracja edukacyjna jest pierwszym krokiem do łączenia rodzin ${ }^{31}$.

Ukraińscy badacze twierdzą też, że wpływ na popularność Polski wśród ukraińskiej młodzieży ma też bliskość geograficzna. Z zachodniej Ukrainy niejednokrotnie szybciej się dostać do Przemyśla, Rzeszowa, Lublina, Chełma, Zamościa niż do Kijowa czy innych miast akademickich na Ukrainie ${ }^{32}$. Przygraniczne położenie polskich uczelni ma duże znaczenie dla młodzieży z zachodniej Ukrainy częściej wybierającej studia w Polsce niż dla młodych $\mathrm{z}$ innych regionów Ukrainy ${ }^{33}$.

Kolejnym czynnikiem mającym wpływ na popularność studiów w Polsce jest przekonanie Ukraińców o ich wyższej jakości. Studia w Polsce, pozwalają na w ich mniemaniu - uzyskanie europejskiego dyplomu, cieszącego się większym

${ }^{26}$ К. Зарембо, Молодь України 2017..., с. 76.

27 Zob. Є. Стадний, Українські студенти в польських ВНЗ...

${ }^{28}$ D. Izdebska-Długosz, Dlaczego Polska?..., s. 71.

29 Zob. О. Слободян, Є. Стадний, Українськ студенти за кордоном...

${ }^{30}$ I. Jóźwiak, M. Piechowska (2017), Crisis-driven Mobility between Ukraine and Poland. What Does the Available Data (Not) Tell Us, „CMR Working Papers”, Vol. 99, p. 6.

${ }_{31}$ Zob. О. Слободян, Є. Стадний, Українськ студенти за кордоном...; J. Bierówka, Opinie studentów ukraińskich..., s. 206; O. Hrynkevych (2017), Cross-border factor of educational migration of Ukrainian youth to Poland: social-economic opportunities and threats, „Economic Annals-XXI”, Vol. 163, Issue 1, pp. 26-30.

32 Zob. Є. Стадний, Украӥнські студенти в польських ВНЗ...

${ }^{33}$ O. Hrynkevych, Cross-border factor of educational..., p. 27. 
prestiżem i zasięgiem od rodzimego, i - tym samym - powiększającego szanse $\dot{z} y$ ciowe $^{34}$. Istotne jest również to, że studia w Polsce dają szanse na skorzystanie z programu Erazmus+ i umożliwiają młodzieży wyjazd na Zachód ${ }^{35}$. Studia w Polsce dają też ukraińskiej młodzieży możliwość uczciwego zdobycia dyplomu, z pomocą własnej pracy, wysiłku i intelektu ${ }^{36}$.

Polska jest traktowana przez Ukraińców jako dobre miejsce do życia, gdzie możliwe jest uzyskanie wyższych zarobków i osiągnięcie lepszego poziomu życia ${ }^{37}$. Wybór studiów w Polsce jest traktowany jako wzrost szans życiowych i zapewnienie sobie bezpiecznej przyszłości. Studia mogą być w tym kontekście postrzegane jako inwestycja w ludzki kapitał. Polska jest wybierana częściej przez ukraińską młodzież, gdyż tutaj stopa zwrotu z wykształcenia wyższego jest relatywnie wyższa. Według danych OECD stopa zwrotu dla mężczyzn wynosiła w państwach OECD i EU 13\%, w Polsce 21\%, w Austrii 8\%, w Czechach 17\%, w Niemczech 12\%, we Włoszech 11\%, Francji 11\%. Dla kobiet wynosiła w Polsce 17\%, Austrii 6\%, Czechach $11 \%$, w Niemczech $7 \%$, we Włoszech $8 \%$, Francji 9\% ${ }^{38}$. Z danych podawanych przez ukraińskich analityków średnia stopa zwrotu $\mathrm{z}$ wyższego wykształcenia wynosiła na Ukrainie 6\%, w krajach EU 43\%, w tym w Polsce 45\%, w Czechach $44 \%$, w Niemczech $32 \%{ }^{39}$.

Emigracja edukacyjna może być także traktowana jako proces europeizacji ukraińskich studentów ${ }^{40}$. Studia w Polsce pozwalają na zbliżenie się do zachodniej kultury oraz tworzą odpowiednią przestrzeń dla indywidualizacji i samorealizacji, na których to ukraińskiej młodzieży zależy coraz częściej¹.

Duże znaczenie w tworzeniu odpowiedniego klimatu na Ukrainie, sprzyjającego wyborowi Polski jako kraju docelowego, ma polityka polskich władz i działania promocyjno-rekrutacyjne podejmowane przez polskie uczelnie. Są one aktywne na Ukrainie, prezentują swoją ofertę na targach edukacyjnych, reklamują się w dużych miastach na bilbordach, tworzą centra doradcze w ośrodkach miejskich ${ }^{42}$. Polskie

${ }_{34}$ Zob. O. Слободян, Є. Стадний, Українськ студенти за кордоном...; M. Pakosz, Rekrutacja kandydatów z Ukrainy..., s. 210; D. Izdebska-Długosz, Dlaczego Polska?...., s. 68; S. Kapera, Motywy wyboru i oczekiwania studentów..., s. 21; V. Cherba, H. Tobol, D. Mushkatiorova, The Reasons of Educational Migrations..., p. 71.

${ }_{35}$ M. Pakosz, Rekrutacja kandydatów z Ukrainy..., s. 205.

${ }^{36}$ M. Gońda (2017), Mobilność edukacyjna w sytuacji migracji do korzeni: polska diaspora na studiach w kraju przodków, „Studia Migracyjne - Przegląd Polonijny”, Vol.1, ss. 229-258.

${ }^{37}$ Zob. O. Слободян, Є. Стадний, Українськ студенти за кордоном...; V. Cherba, H. Tobol, D. Mushkatiorova, The Reasons of Educational Migrations..., c.71.

${ }^{38}$ Education at a Glance 2017..., p. 129-130.

39 Zob. O. Слободян, Є. Стадний, Українськ студенти за кордоном...

${ }^{40}$ M. Gońda, Mobilność edukacyjna w sytuacji migracji..., s. 239; O. Hrynkevych, Cross-border factor of educational..., p. 26.

${ }^{41}$ Zob. D. Izdebska-Długosz, Dlaczego Polska?...., s. 67. M. Gońda, Mobilność edukacyjna w sytuacji migracji..., s. 239.

42 O. Hrynkevych, Cross-border factor of educational..., p. 27-28. 
uczelnie mają też wsparcie w postaci kampanii „Ready, Study, Go POLAND” lub „Study in Poland”, „Study in Lublin”. Ważne jest, że polskie uczelnie mają dobrą markę na Ukrainie ${ }^{43}$.

Na wyjazdy młodzieży z Ukrainy i poszukiwanie bezpiecznej przystani w Polsce może mieć też wpływ wewnętrzna sytuacja Ukrainy. Wprowadzane reformy i trwający konflikt zbrojny na wschodzie kraju negatywnie wpływają na gospodarkę i poziom życia. Walki frakcyjne na szczytach władzy oraz polityczna niepewność sprzyjają powstaniu anomii, a ta sprzyja podejmowaniu działań ucieczkowych.

Reasumując, należy stwierdzić, iż za emigrację edukacyjną ukraińskiej młodzieży do Polski odpowiedzialnych jest kilka czynników. Niewątpliwie proces ten wpisuje się w globalne trendy internalizacji szkolnictwa wyższego. Młodzież ukraińska w ten sposób może też wyrażać chęć integracji z Zachodem, o czym świadczy przewaga wyjazdów młodzieży na studia na Zachód a nie na Wschód. Poza globalnymi czynnikami wpływ na wybór Polski jako kraju docelowego ma bliskość kulturowo-językowa oraz geograficzna. Polskie uczelnie posiadają też dobrą opinię na Ukrainie i są tańsze niż zachodnie. Wybór Polski może być też związany z istnieniem dużej diaspory ukraińskiej i rozbudowaną siecią relacji pomiędzy wieloma ukraińskimi emigrantami zarobkowymi i edukacyjnymi. Z jednej strony, Polska staje się modna wśród młodzieży szukającej zagranicznej przygody i chcącej poznawać świat. $Z$ drugiej strony, rodziny mogą w ten sposób integrować się ze sobą, gdyż dzieci przyjeżdżają na studia do kraju, gdzie niejednokrotnie mieszkają już ich rodzice. Brak stabilizacji politycznej na Ukrainie może wzmacniać ten trend. Generalnie, emigracja edukacyjna jest podporządkowana dążeniom do uzyskania dobrej pracy, wysokiego statusu materialnego i cywilizacyjnego. Polski dyplom jest najbardziej dostępny i pożądany, daje największe szanse na spełnienie tych planów.

\section{Założenia teoretyczne badań}

W większości prac poświęconych emigracji edukacyjnej stosuje się model Everetta S. Lee, określany jako push-pull theory ${ }^{44}$. W analizach emigracji ukraińskich studentów również próbuje się wykorzystywać tę teorię ${ }^{45}$. Zakłada ona, iż decyzje dotyczące wyjazdu na studia do Polski podejmowane są w kontekście czynników wypychających i przyciągających. Jeśli będą oddziaływały czynniki wypychające

${ }^{43}$ M. Pakosz, Rekrutacja kandydatów z Ukrainy..., s. 205.

${ }_{44}$ T. Mazzarol, N.G. Soutar, „Push-pull” factors..., p. 62; О. Козієвська (2013), Академічна мобільність: причини вибору навчання за кордоном, „Вища освіта України”, Vol. 1, с. 89.

${ }^{45}$ O. Bilyakovska, Ukrainian Student Migration..., p. 293.; V.B. Rodchenko, G.P. Rekun, Y.I. Prus (2017), External academic mobility of students: case for Ukraine, „Handel Wewnętrzny”, Vol. 336, Issue 1, p. 64. 
w danym kraju, wówczas młodzież będzie skłonna go opuścić. Zaś o wyborze docelowego miejsca migracji edukacyjnej decydować będą czynniki przyciągające.

Na podstawie literatury przedmiotu i analizy dotychczasowych ustaleń została przygotowana lista owych czynników - przedstawiona w tabeli 1.

Tabela 1 .

Czynniki wypychające i przyciągające w emigracji ukraińskich studentów do Polski

\begin{tabular}{|c|c|}
\hline $\begin{array}{l}\quad \text { Push factors (Ukraina) } \\
\text { - Anomia systemu społeczno-politycz- } \\
\text { nego } \\
\text { - Recesja gospodarki } \\
\text { - Korupcja i brak merytokracji } \\
\text { - Brak popytu na specjalistów } \\
\text { - Niska jakość nauczania na uczelniach } \\
\text { wyższych } \\
\text { - Niski prestiż dyplomu } \\
\text { - Brak nowoczesnej infrastruktury i la- } \\
\text { boratoriów na uczelniach } \\
\text { - Relatywnie wysokie koszty studiowa- } \\
\text { nia } \\
\text { - Autorytatywny system szkolnictwa }\end{array}$ & $\begin{array}{l}\text { Pull factors (Polska) } \\
\text { - Możliwość uzyskania europejskiego dyplomu } \\
\text { i otwarcie na europejski rynek pracy } \\
\text { - Wysoka jakość i prestiż polskich uczelni } \\
\text { - Możliwość skorzystania z oferty stypendialnej } \\
\text { i programu Erazmus + wraz ze stypendium } \\
\text { - Niskie koszty studiowania w porównaniu do } \\
\text { innych państw zachodnich } \\
\text { - Lepsza oferta pracy i wyższe płace } \\
\text { - Wyższy standard życia } \\
\text { - Bliskość geograficzna i kulturowa (językowa) } \\
\text { - Rozbudowane sieci migracyjne } \\
\text { - Stabilna sytuacja polityczna i ekonomiczna } \\
\text { - Członkostwo w Unii Europejskiej }\end{array}$ \\
\hline
\end{tabular}

Źródło: Opracowanie własne

Czynniki wypychające muszą mieć dużą moc oddziaływania, gdyż jak pokazują badania znaczny odsetek studentów zamierza opuścić Ukrainę ${ }^{46}$. Wybierając się na studia do Polski młodzież twierdzi, że ta opcja jest najlepsza z możliwych i daje znaczny wzrost szans życiowych.

Do eksplikacji emigracji ukraińskiej młodzieży do Polski stosuje się też model inwestycji w kapitał ludzki ${ }^{47}$. Edukacja w tym ujęciu stanowi inwestycję ekonomiczną przynoszącą odpowiednie stopy zwrotu w postaci wysokości zarobków ${ }^{48}$. $\mathrm{W}$ tej perspektywie emigracja ukraińskiej młodzieży jest traktowana jako wynik

${ }_{46} \mathrm{Z}$ badań zrealizowanych wśród młodzieży na Ukrainie wynikało, że 36\% planowało wyjazd na studia za granicę, $40 \%$ wyjechałoby, ale nie ma odpowiednich środków, a $25 \%$ nie chce opuszczać Ukrainy. V. Cherba, H. Tobol, D. Mushkatiorova, The Reasons of Educational Migrations..., p. 69. Wśród studentów ze Lwowa chciałoby wyjechać do pracy za granicę $82 \%$, wyjechać na studia za granicę 72\%, zamieszkać za granicą 38\%. І. Ключковська, Ю. Марусик, О. П’ятковська (2014), Звim про результати дослідження міграційних настроїв студентів Львова, Львів, с. 11-12. http:// miok.lviv.ua/wp-content/uploads/2015/04/zvitpj.pdf. dostęp 20.11.2017.

${ }^{47}$ Zob. О. Слободян, Є. Стадний, Украйнськ студенти за кордоном...

${ }^{48}$ Zob. G.S. Becker (1962), Investment in Human Capital: A Theoretical Analysis, „Journal of Political Economy", Vol. 70, pp. 9-49; J. Mincer (1974), Schooling, Experience and Earnings. National Bureau of Economic Research, New York: Columbia University Press. 
racjonalnej kalkulacji zakładającej, że warto inwestować w wykształcenie, gdyż daje ono odpowiednią stopę zwrotu. Polska jest wybierana przez młodzież dlatego, że stopa zwrotu $\mathrm{z}$ wykształcenia jest wysoka ${ }^{49}$. Inwestycja $\mathrm{w}$ studia wyższe będzie przynosić zdaniem młodzieży wyższe korzyści poza granicami Ukrainy. Zauważa się też, że ukraińska młodzież traktuje studia w Polsce jako inwestycję w europejskie wykształcenie, które będzie przynosiło wyższe dochody w krajach Europy Zachodniej. Na ten fakt zwracali uwagę badacze w swoich pracach ${ }^{50}$.

Do analizy emigracji edukacyjnej można też wykorzystać teorię systemu światowego, w której pojawia się podział świata na centrum, półperyferie i peryferie ${ }^{51}$. Zazwyczaj strumień migracyjny prowadzi z krajów biedniejszych do bogatszych. Polska w systemie światowym stanowi półperyferia, Ukraina peryferia. Rdzeniem, czyli krajami centrum, będą państwa starej Unii Europejskiej. Emigracja według tego wzorca prowadzi z peryferii do półperyferii, by później przejść do jednego z państw rdzenia. Studia w Polsce, a raczej europejski dyplom polskiej uczelni, może być traktowany jako przepustka pozwalająca na przedostanie się do krajów centrum. Polskie uczelnie stają się w tym kontekście atrakcyjne dla Ukraińców, gdyż stanowią tańszą alternatywę zachodnich uczelni. Wydają certyfikaty umożliwiające uzyskanie pracy w krajach Unii Europejskiej. W tym ujęciu Polska stanowi trampolinę, która pozwala na odbicie i dotarcie na Zachód. Szczególnie najnowsze badania udowadniają, że młodzi Ukraińcy częściej zamierzali po skończeniu studiów wyjechać do pracy do państw zachodnich niż pozostać na stałe w Polsce ${ }^{52}$.

W nawiązaniu do tego podejścia można wskazać na postkolonialny charakter migracji edukacyjnych. Często się zdarza, że młodzież z byłych kolonii wyjeżdża na studia do stolicy imperium ${ }^{53}$. W tym przypadku można mówić o emigracjach poimperialnych ${ }^{54}$. W analizowanym przypadku duże znaczenie dla migracji mogą mieć związki historyczne łączące Zachodnią Ukrainę z Polską. Przed 1939 r. zachodnia Ukraina leżała w granicach II Rzeczypospolitej. Na ten fakt może wskazywać emigracja edukacyjna do Polski Ukraińców polskiego pochodzenia oraz przewaga wśród migrantów młodzieży pochodzącej z zachodniej Ukrainy.

${ }^{49}$ Education at a Glance 2017 2017..., p. 212.

50 D. Izdebska-Długosz, Dlaczego Polska?...., s. 69; M. Gońda, Mobilność edukacyjna w sytuacji migracji...., s. 238.

${ }^{51}$ Zob. I. Wallerstein (2011), The modern world-system I: Capitalist agriculture and the origins of the European world-economy in the sixteenth century, with a new prologue, San Francisco: University of California Press.

${ }_{52}$ Zob. D. Izdebska-Długosz, Dlaczego Polska?...s. 69; M. Gońda, Mobilność edukacyjna w sytuacji migracji..., s. 238.

53 T. Mazzarol, N.G. Soutar, „Push-pull” factors..., p. 4.

${ }^{54}$ Z. Brunarska (2013), Współczesne migracje na obszarze poradzieckim przez pryzmat koncepcji migracji poimperialnych, „Central and Eastern European Migration Review”, Vol. 2, Issue 2, pp. 39-54.; U. Bosma, J. Lucassen, G. Oostindie G. (eds.) (2012), Postcolonial Migrants and Identity Politics: Europe, Russia, Japan and the United States in Comparison, Berghahn Books: New York and Oxford. 


\section{Metodologia badań}

Materiał stanowiący bazę empiryczną analiz pochodzi z dwóch badań zrealizowanych w 2015 r. i 2017 r. Dane zostały połączone w celu zwiększenia rzetelności pomiaru. W pierwszej turze badań sondaż został zrealizowany w Państwowej Szkole Wschodnioeuropejskiej w Przemyślu na próbie 104 respondentów i Wyższej Szkole Informatyki i Zarządzania w Rzeszowie wśród 146 studentów. W drugiej fali badań pomiarem objęto 110 osób w Państwowej Wyższej Szkole Wschodnioeuropejskiej w Przemyślu, 113 respondentów w Wyższej Szkole Zarządzania i Informatyki w Rzeszowie, 39 osób w Krakowskiej Akademii Frycza Modrzewskiego i 94 studentów na Uniwersytecie Pedagogicznym w Krakowie ${ }^{55}$. Łącznie uzyskano 606 ankiet. Badania zostały wykonane za pomocą metody sondażowej. Do zbierania materiału badawczego została wykorzystana ankieta audytoryjna. Kwestionariusz ankiety zawierał pytania w języku polskim. Pomiary prowadzono wśród studentów na kierunkach ekonomicznych, społecznych, humanistycznych, medycznych. Respondenci byli studentami trzeciego roku studiów licencjackich, prowadzonych $\mathrm{w}$ języku polskim ${ }^{56}$. Próba do badań miała charakter okazjonalny. Przebadano studentów dostępnych na zajęciach. Uzyskany materiał badawczy, poza kilkoma przypadkami nieprawidłowo wypełnionych ankiet, został wprowadzony do bazy danych i poddany analizie za pomocą programu SPSS.

W związku z tym, że próba do badań miała charakter celowy i pochodziła ona spośród studentów ukraińskich studiujących na terenach południowo-wschodniej Polski należy z ostrożnością podchodzić do formułowania wniosków. Mimo że prowadzone badania nie mają statusu reprezentatywności, pozwalają jednak na poznanie mechanizmów imigracji edukacyjnej wśród ukraińskiej młodzieży i jej integracji w warunkach małych i średnich miast. Wyniki badań można potraktować jako studium przypadku pokazujące mechanizmy procesów imigracji ukraińskich studentów do Polski. Realizacja badań w trzech typach ośrodków akademickich pozwala na prześledzenie procesu imigracji w małych, średnich i dużych miastach akademickich.

Prowadzone badania mają na celu dostarczenie wiedzy na temat imigracji ukraińskiej młodzieży na studia do Polski. Główne pytanie badawcze dotyka tego, w jakim stopniu o wyjeździe z Ukrainy na studia do Polski decydują czynniki wypychające $v s$ przyciągające. Istotne będzie też przedstawienie mechanizmów integracji ukraińskich studentów w zróżnicowanym środowisku pod względem wielkości ośrodka akademickiego. Do problemów cząstkowych można zaliczyć następujące:

${ }^{55}$ Państwowa Wyższa Szkoła Wschodnioeuropejska oraz Uniwersytet Pedagogiczny są uczelniami publicznymi. Wyższa Szkoła Zarządzania i Informatyki w Rzeszowie oraz Akademia Krakowska są uczelniami prywatnymi.

${ }^{56}$ O przygotowaniu kwestionariusza $\mathrm{w}$ języku polskim zadecydowały badania pilotażowe oraz to, że studenci byli na studiach $\mathrm{z}$ językiem polskim. 
- Jakie są przyczyny wyboru studiów na polskich uczelniach?

- Jakie problemy pojawiają się w związku z przeprowadzką na studia do Polski?

- Jak studenci oceniają swoje funkcjonowanie w trakcie studiów w Polsce?

- Jakie są plany studentów związane z ukończeniem studiów w Polsce?

- Czy typ ośrodka akademickiego ma wpływ na mechanizmy integracji ?

Wśród respondentów było 61\% kobiet i 39\% mężczyzn. Najwięcej było absolwentów liceum ogólnokształcącego (74\%), rzadziej liceum zawodowego (13\%) oraz technikum (13\%). Spośród badanych $82 \%$ pochodziło z miasta, a $18 \%$ ze wsi. Biorąc pod uwagę region pochodzenia, najwięcej pochodziło z zachodniej Ukrainy - 66\%. Rzadziej byli to studenci pochodzący z Ukrainy centralnej (27\%), wschodniej (4\%), czy też południowej (3\%). Własną sytuację finansową jako złą oceniło $16 \%$ badanych, jako średnią $54 \%$, jako dobrą $26 \%$. Miarą statusu społecznego jest pozycja zawodowa i wykształcenie ojca. Wśród przebadanych ojców studentów $17 \%$ miało posiadało wyższy status zawodowy. Spośród ojców badanych $15 \%$ stanowili pracownicy średniego szczebla, $13 \%$ przedsiębiorcy, a $10 \%$ pracowało w usługach. Na stanowiskach robotniczych pracowało 14\% ojców respondentów. Około 17\% stanowiły dzieci ojców bezrobotnych oraz rencistów i emerytów, a 3\% rolników. Kategorię inne wybrało 7\%. Wśród ojców respondentów 9\% posiadało wykształcenie zawodowe i niższe. Średnie wykształcenie posiadało $41 \%$. Wyższe wykształcenie posiadało 50\%. Średnia ocen badanych z egzaminu maturalnego wynosiła 9,0 a mediana 9,8. Spośród respondentów 56\% korzystało z korepetycji w szkole średniej. Zadowolonych z własnego życia było 83\%. Niezadowolonych z życia było $13 \%$, nie potrafiło ocenić swojego stanu $5 \%$. Wierzących było $76 \%$, niezdecydowanych 15\%, niewierzących $9 \%$.

\section{Wyniki badań}

W dyskursie na temat przyczyn emigracji ukraińskich studentów do Polski pojawia się kwestia rzekomego braku atrakcyjnych kierunków studiów na Ukrainie, w związku z czym młodzież jest zmuszona do poszukiwania studiów za granicą̨ Wśród przebadanych studentów 64\% stwierdziło, że taki kierunek, na jakim obecnie studiują w Polsce, był w ofercie edukacyjnej uczelni na Ukrainie, a jedna czwarta, że tego kierunku brakowało. 10\% nie potrafiło udzielić odpowiedzi. W związku z powyższym, trudno zgodzić się z tezą, że studenci ukraińscy przyjeżdżają do Polski na studia, gdyż nie mają atrakcyjnych kierunków u siebie. Mimo że mogą podjąć zamierzone studia w swoim kraju, wolą przyjechać na studia do Polski. Dodatkowym argumentem potwierdzającym tę tezę jest fakt, że większość badanych studiuje kierunki społeczne, humanistyczne, inżynieryjne, zdrowotne, które

57 Zob. О. Слободян, Є. Стадний, Украӥнськ студенти за кордоном... 
są dostępne na Ukrainie ${ }^{58}$. Należy też pamiętać, że w ukraińskich uczelniach spada liczba studentów, dlatego władze państwa oraz uczelni starają się modernizować studia i kierunki tak, aby stawały się one bardziej atrakcyjne dla maturzystów.

Tabela 2.

Przyczyny wyboru studiów w Polsce (dane podano w procentach) ${ }^{59}$

\begin{tabular}{|l|c|}
\hline Aby mieć dyplom zagranicznego uniwersytetu & 72 \\
\hline Aby poznać świat & 64 \\
\hline Bo tutaj jest wyższy poziom nauczania, lepsze wykształcenie & 42 \\
\hline Aby mieć europejski dyplom, który umożliwi wyjazd na Zachód & 38 \\
\hline Łatwiej po tych studiach będzie znaleźć pracę, zrobić karierę & 37 \\
\hline Ciekawsze życie towarzyskie, możliwość atrakcyjnego spędzania czasu wolnego & 35 \\
\hline Bo tutaj mogę lepiej realizować się, rozwijać swoje zainteresowania & 31 \\
\hline Bo jest to uczelnia najbliżej położona mojego domu & 30 \\
\hline Lubię poznawać nowe miejsca & 29 \\
\hline Dzięki studiom mogę wyjechać z mojego kraju & 27 \\
\hline Bo jest lepiej żyć w wysokim standardzie materialnym & 25 \\
\hline Tutaj są lepiej wyposażone laboratoria i biblioteki & 21 \\
\hline $\begin{array}{l}\text { Bo nie ma korupcji, nie trzeba dodatkowo płacić wykładowcom za egzaminy i za- } \\
\text { liczenia }\end{array}$ & 20 \\
\hline Bo jest bezpiecznie, z dala od konfliktu i wojny & 19 \\
\hline Łatwiej się usamodzielnić, sprawdzić swoje możliwości & 15 \\
\hline Bo jest demokracja i wolność słowa & 15 \\
\hline
\end{tabular}

Źródło: badania własne

Odpowiedzi uzyskane od respondentów pokazują motywy, którymi się kierowali młodzi Ukraińcy, decydując się na studia w Polsce. Najczęściej wybieraną odpowiedzią była chęć uzyskania dyplomu zagranicznego uniwersytetu (72\%) oraz aby lepiej poznać świat (64\%). W dalszej kolejności były wymienione takie motywy, jak: wyższy poziom nauczania, lepsze wykształcenie (42\%), europejski dyplom umożliwiający podjęcie prace na Zachodzie (38\%), łatwiej będzie po tych studiach znaleźć pracę, zrobić karierę (37\%), ciekawsze życie towarzyskie (35\%), możliwość samorozwoju (31\%). Ukraińscy studenci zaznaczali też odpowiedzi mówiące, że

58 Zob. Є. Стадний, Украӥнські студенти в польських ВНЗ...

${ }^{59}$ Odpowiedzi nie sumują się do $100 \%$ ponieważ można było wybrać dowolną liczbę odpowiedzi pasujących do sytuacji respondenta. 
wybierali studia w Polsce ze względu na to, że była to uczelnia położona blisko domu (30\%), że lubią poznawać nowe miejsca (29\%), że studia umożliwiły wyjazd z kraju (27\%), że w Polsce jest wyższy standard życia (25\%), lepiej wyposażone są biblioteki i laboratoria (21\%). Zwracano też uwagę, że nie ma korupcji (20\%), jest bezpiecznie z dala od konfliktu i wojny (19\%), łatwiej się usamodzielnić i sprawdzić swoje umiejętności (15\%), jest demokracja i wolność słowa (15\%).

Biorąc pod uwagę najczęściej wymieniane motywy wyjazdu na studia do Polski, należy stwierdzić, że przeważają te o charakterze przyciągającym. Młodzieży ukraińskiej zależy na zagranicznym wykształceniu, gdyż ono zwiększa szanse życiowe. $\mathrm{Z}$ wielu względów, o których już pisano, Polska najlepiej wpisuje się w realizację tych potrzeb, co sprawia, że jest najczęściej wybierana przez ukraińską młodzież. Wyniki badań pokazują też, że korupcja oraz wojna na wschodzie Ukrainy w niewielkim stopniu mają wpływ na decyzje dotyczące emigracji młodzieży ukraińskiej. Raczej za emigrację odpowiedzialne są tendencje indywidualizacyjne pojawiające się w nowoczesności. W sytuacji, gdy młodzież zaczyna większą wagę przykładać do własnego rozwoju i zaspokojenia swoich potrzeb, musi sama budować i brać odpowiedzialność za swoją biografię, to dyplom zagranicznej uczelni wydaje się najlepszym środkiem pozwalającym uzyskać te cele. Uzyskane wyniki potwierdzają także badania realizowane wśród studentów zagranicznych w Polsce w 2016 r. Studenci z Ukrainy wskazywali najczęściej, że przyjazd do Polski był motywowany tym, że są to studia w kraju Unii Europejskiej (57\%), że studia zapewniają dobre perspektywy zawodowe (52\%) oraz to, że polski dyplom ma międzynarodową uznawalność $(48 \%)^{60}$.

Po przyjeździe na studia do Polski pojawiają się różne problemy związane z przystosowaniem do nowego środowiska i studiów w polskich uczelniach. Należy pamiętać, iż na studia do Polski przyjeżdżają bardzo młodzi ludzie mający 16-17 lat. $\mathrm{Z}$ tego tytułu mogą mieć większe problemy z adaptacją.

Głównym problemem po przyjeździe do Polski są kwestie ekonomiczne (45\%). Nie dziwi to, gdyż młodzież ukraińska przyjeżdża z biedniejszego kraju i musi sobie radzić z wysokimi kosztami utrzymania plus opłaty czesnego. Trudność sprawia też studentom nieznajomość języka polskiego (43\%). Większość wybiera studia w języku polskim, w związku z tym, zarówno na uczelni, jak też poza nią brak znajomości języka może znacznie utrudniać funkcjonowanie w Polsce. Na emigracji doskwiera młodzieży także tęsknota za rodziną, znajomymi (39\%). W integracji w nowym społeczeństwie przeszkadza też to, że młodzież ukraińska przebywa głównie w swoim gronie, izolując się (zwykle przymusowo - akademiki) od polskich rówieśników (35\%). W dalszej kolejności wymieniano kłopoty ze znalezieniem mieszkania

${ }^{60}$ Badania prowadzone były na próbie 2660 respondentów metodą sondażu online. Analizowane odpowiedzi zostały uzyskane wśród 900 studentów ukraińskich studiujących w Polsce na studiach licencjackich w 2016 r. A. Stasik, Raport z badania ankietowego..., s. 9. 
(21\%), wspólne zamieszkiwanie i przebywanie tylko ze swoimi rodakami (20\%), samotność (17\%). Część odpowiedzi wskazywało, że respondentom doskwierała też trudność ze znalezieniem przyjaciół i znajomych (13\%), lęk i obawa o życie rodziny pozostającej na Ukrainie (13\%), trudność w kontaktach z urzędami (11\%), problem ze znalezieniem się w środowisku wielkomiejskim (6\%). Warto odnotować, że $15 \%$ odpowiedzi dotyczyło tego, że młodzież nie miała żadnych problemów $\mathrm{z}$ adaptacją do polskich realiów.

Tabela 3 .

Problemy pojawiające się po przyjeździe na studia do Polski (dane podano w procentach) ${ }^{61}$

\begin{tabular}{|l|c|}
\hline Brak pieniędzy, drogie życie i wysokie koszty utrzymania & 45 \\
\hline Nieznajomość języka & 43 \\
\hline Tęsknota za rodziną, znajomymi & 39 \\
\hline Zbyt mały kontakt z Polakami & 35 \\
\hline Kłopoty ze znalezieniem mieszkania & 21 \\
\hline Mieszkanie, przebywanie i uczenie się tylko z Ukraińcami & 20 \\
\hline Samotność & 17 \\
\hline Nie miałem(am) problemów, pokonywałem(am) wszystkie niedogodności & 15 \\
\hline Trudności ze znalezieniem znajomych, przyjaciół & 13 \\
\hline Lęk i obawa o życie rodziny i znajomych pozostających na Ukrainie & 13 \\
\hline Trudności związane z kontaktami z instytucją, urzędami & 11 \\
\hline Problem odnalezienia się w środowisku wielkomiejskim & 6 \\
\hline Inny problem, jaki & 4 \\
\hline Problemy logistyczne & 1 \\
\hline
\end{tabular}

Źródło: badania własne

Uzyskane rezultaty wskazują, że młodzież musi sobie radzić w Polsce z problemami ekonomicznymi i językowymi. Ważną kwestią jest też separacja ukraińskiej młodzieży w środowisku społecznym. Młodzież się izoluje i przez to ma problem z nauką języka i asymilacją. Można zauważyć, iż może następować tutaj sprzężenie zwrotne między brakiem znajomości języka a zamykaniem się i ograniczeniem kontaktów z polskimi rówieśnikami.

Do pomiaru zadowolenia ze studiów zastosowano skalę szacunkową z następującymi wartościami: bardzo nisko - 1 , nisko -2 , średnio - 3, wysoko - 4, bardzo

${ }^{61}$ Odpowiedzi nie sumują się do $100 \%$, ponieważ można było wybrać dowolną liczbę odpowiedzi pasujących do sytuacji respondenta. 
wysoko - 5. Uzyskane niskie średnie świadczą o niskich ocenach respondentów, a wyższe średnie wskazują na wystawianie wyższych ocen.

Najwyżej ukraińscy studenci ocenili dostępność cyfrowej infrastruktury w postaci Internetu i komputerów $(4,06)$. Dobre oceny uzyskało też nastawienie wykładowców do studentów $(3,86)$. Podobnie noty otrzymała obsługa dziekanatu i sekretariatu $(3,70)$. Wysoko oceniono też komunikację miejską $(3,68)$ oraz poziom nauczania na uczelni $(3,61)$. Pozytywnie oceniono życzliwość mieszkańców miasta wobec studentów $(3,51)$. Podobnie przedstawiała się ocena programu studiów $(3,49)$.

Niżej oceniono możliwość spędzania wolnego czasu przez studentów $(3,48)$, możliwość rozwijania swoich zainteresowań na uczelni $(3,44)$, ofertę kulturalną miasta $(3,43)$. Gorsze oceny uzyskał rozkład zajęć na studiach $(3,40)$, możliwość realizacji swoich zainteresowań $(3,33)$. Najsłabiej zostały ocenione ceny towarów i usług $(3,29)$, możliwość znalezienia dobrej pracy po studiach $(3,21)$ oraz możliwość znalezienia pracy w trakcie studiów $(2,29)$.

Tabela 4

Ocena pobytu na studiach w Polsce (dane podane w średnich)

\begin{tabular}{|l|c|c|}
\hline \multicolumn{1}{|c|}{ Kategorie } & Średnia & $\begin{array}{c}\text { Odchylenie } \\
\text { standardowe }\end{array}$ \\
\hline Dostępność na uczelni do Internetu, komputerów & 4,06 & 0,99 \\
\hline Życzliwość wykładowców & 3,86 & 0,87 \\
\hline Obsługa dziekanatów, sekretariatów & 3,70 & 0,93 \\
\hline Komunikacja miejska & 3,68 & 0,87 \\
\hline Poziom nauczania na uczelni & 3,61 & 0,91 \\
\hline Życzliwość mieszkańców miasta & 3,51 & 0,98 \\
\hline Program studiów & 3,49 & 0,92 \\
\hline Możliwość spędzania wolnego czasu & 3,48 & 0,92 \\
\hline Możliwość rozwijania swoich zainteresowań na uczelni & 3,44 & 2,94 \\
\hline Ciekawa oferta kulturalna & 3,43 & 0,92 \\
\hline Rozkład zajęć na studiach & 3,40 & 0,95 \\
\hline Możliwość realizacji swoich zainteresowań & 3,33 & 0,95 \\
\hline Rozsądne ceny w mieście (ceny mieszkania, żywność, rozrywki) & 3,29 & 0,99 \\
\hline Możliwość znalezienia dobrej pracy po studiach & 3,21 & 0,97 \\
\hline Możliwość znalezienia pracy w czasie studiów & 2,91 & 1,09 \\
\hline
\end{tabular}

Źródło: badania własne 
Badania pokazują, że studenci z Ukrainy najlepiej oceniają jakość i warunki studiowania na polskich uczelniach. Według nich polskie uczelnie są nowoczesne, dobrze zorganizowane, a studenci są tam odpowiednio traktowani. Być może ta pozytywna opinia rozchodząca się w środowisku studenckim stanowi najważniejszy czynnik sprawiający, że polskie uczelnie są wyjątkowo atrakcyjne dla ukraińskich studentów. Na ten fakt może mieć też wpływ to, że na Ukrainie szkolnictwo boryka się z kłopotami finansowymi, a infrastruktura techniczna jest $\mathrm{w}$ nienajlepszym stanie, zaś system szkolny jest autorytarny. Na pojawienie się relacji poziomych między studentami a pracownikami uczelni zwracali uwagę studenci w badaniach jakościowych ${ }^{62}$. Po przyjeździe do Polski mogą oni być pozytywnie zaskoczeni warunkami studiów. Za efektem kontrastu przemawiają też badania prowadzone wśród zagranicznych studentów w Polsce. Najbardziej zadowoleni ze studiów na polskich uczelniach byli studenci ze wschodu Europy, a najgorzej ocenili je studenci z zachodniej Europy ${ }^{63}$. Wysoko oceniono także życzliwość mieszkańców miast wobec studentów. Obserwacja ta zasługuje na podkreślenie, gdyż studenci jednak w większości (poza Krakowem) byli badani w małych miastach na „ścianie wschodniej", gdzie można by się spodziewać postaw ksenofobicznych i nietolerancyjnych wobec nich. Jednakże wysoka ocena relacji z mieszkańcami miast świadczy, że studenci są pozytywnie odbierani przez lokalne społeczności. Jeśli taka opinia jest propagowana wśród tych, którzy kończą studia w Polsce, to niewątpliwie jest to kapitał, który wykorzystuje się w rekrutacji ukraińskiej młodzieży na studia do Polski ${ }^{64}$. Być może sympatia Polaków do ukraińskich studentów wynika też z sytuacji, w jakiej znajduje się ukraińskie społeczeństwo poddane kryzysowi i konfliktowi zbrojnemu na wschodzie Ukrainy.

Najgorzej oceniają ukraińscy studenci ekonomiczne warunki bytowania w Polsce. Z jednej strony, na obniżenie poziomu satysfakcji ze studiów mają wpływ wysokie koszty utrzymania. Należy pamiętać, że sytuacja ekonomiczna Ukrainy, relacja hrywny do złotego są niekorzystne. W związku z tym życie w Polsce jest drogie. $\mathrm{Z}$ drugiej strony, badani studenci narzekali na trudności w znalezieniu pracy zarówno w trakcie studiów, jak też po nich. Należy dodać, że w niekorzystnej sytuacji będą ukraińscy studenci studiujący w mniejszych miastach, w których sektor usług rynkowych jest słabo rozwinięty. Lepiej pod tym względem mają studenci z dużych miast akademickich, gdzie gospodarka jest lepiej rozwinięta i panuje popyt na pracę $\mathrm{w}$ usługach, a absolwenci uczelni łatwiej znajdują zatrudnienie. Być może $\mathrm{z}$ tego powodu w ostatnich latach zaczęła spadać liczba ukraińskich studentów przyjeżdżających na Podkarpacie. Obecnie częściej biorą oni pod uwagę szansę na

${ }^{62}$ J. Bierówka, Opinie studentów ukraińskich..., s. 205.

${ }^{63}$ A. Stasik, Raport z badania ankietowego „Zagraniczni studenci 2015/16”..., s. 12.

${ }^{64}$ Studenci z Ukrainy w 98\% byli skłonni polecić swoim rówieśnikom studia w Polsce. Oni też byli w grupie studentów najbardziej zadowolonych ze studiów w Polsce; Ibidem, s. 16. 
znalezienie pracy w trakcie i po studiach, w związku z tym mogą podążać w kierunku dużych ośrodków akademickich.

Zapytano też badanych czy są zadowoleni ze studiowania w polskiej uczelni. Pozytywnie na to pytanie odpowiedziało $92 \%$, w tym $35 \%$ zdecydowanie tak, a 58\% raczej tak. Uzyskane odpowiedzi potwierdzają pozytywne opinie młodych Ukraińców o studiach w Polsce. Rzadziej jednak respondenci wyrażali przekonanie, że wiedza i umiejętności zdobyte w trakcie studiów zapewnią im dobrą pracę. Wśród badanych $62 \%$ tak uważało, $28 \%$ miało odmienne zdanie, a $10 \%$ nie potrafiło odpowiedzieć na to pytanie.

Studenci po zakończeniu studiów licencjackich w większości zamierzają kontynuować naukę na studiach magisterskich (49\%). Część z nich zamierza jednocześnie studiować i pracować (25\%). Są też tacy, którzy chcą jednocześnie studiować i założyć własną firmę (7\%). Założyć własną firmę chce $4 \%$, a pójść tylko do pracy $14 \%$ badanych. Wśród respondentów jedynie $2 \%$ nie miało sprecyzowanych planów zawodowych po ukończeniu studiów licencjackich.

Zdecydowana większość, bo aż $81 \%$ respondentów, zamierza kontynuować studia magisterskie. Odpowiedzi te pokazują, iż ukraińscy studenci mają wysokie aspiracje edukacyjne. Chcą zakończyć studia $\mathrm{z}$ tytułem magistra. Ponad $1 / 3 \mathrm{z}$ nich planuje łączenie studiów z pracą zawodową. Interesujące jest to, że ukraińska młodzież postępuje zgodnie z wyzwaniami rynku pracy, gdyż w Polsce stopa zwrotu ze studiów licencjackich jest niewielka, a dopiero skończenie studiów magisterskich daje wyższą stopę zwrotu ${ }^{65}$.

Pozostaje jeszcze do omówienia kwestia planów życiowych ukraińskich studentów. Ponad połowa badanych zamierza pozostać w Polsce (55\%). Wyjechać do innego kraju (głównie Niemcy i USA) zamierza 33\%, zaś wrócić na Ukrainę planuje tylko $13 \%$. Warto dodać, że podobne wyniki uzyskano w trakcie badań studentów ukraińskich realizowanych w Polsce. Według danych, 56\% ${ }^{66}$ młodych Ukraińców zamierza pozostać w Polsce po skończonych studiach.

Wyniki analiz pokazują, że państwo ukraińskie nie będzie miało zbyt wiele korzyści ze studentów wyjeżdżających na studia do Polski. Za to Polska będzie mogła spożytkować kapitał ludzki i wykorzystać go do rozwoju społeczno-ekonomicznego. Częściowo także państwa zachodniej Europy mogą liczyć na zasilenie swojego rynku pracy ukraińskimi absolwentami polskich uczelni. Oczywiście należy jeszcze pamiętać, iż są to tylko deklaracje. A życie pokaże na ile te plany uda się zrealizować.

Prowadzone analizy pozwoliły tez ustalić uwarunkowania strategii życiowych ukraińskich studentów. Na Ukrainę częściej zamierzali powrócić studenci pewni

${ }^{65}$ J. Czapiński, T. Panek (red.) (2015), Diagnoza społeczna 2015, Warszawa: Rada Monitoringu Społecznego, s. 238.

${ }^{66}$ A. Stasik, Raport z badania ankietowego „Zagraniczni studenci 2015/16”..., s. 18. 
tego, że obecny kryzys na Ukrainie ma charakter przejściowy, a sytuacja w ojczyźnie będzie się poprawiać. Byli też przekonani, że na Ukrainie młodzież może realizować swoje cele życiowe. Częściej też do powrotu dążyli studenci niż studentki. Emigrantów powrotnych cechował też niższy status społeczny. Ich ojcowie mieli niższe wykształcenie i niższy status zawodowy. Wrócić do swojej ojczyzny zamierzają też częściej ci, którzy są bardziej sceptyczni wobec integracji Ukrainy z Unią Europejską.

Ci zaś, którzy zamierzają pozostać w Polsce, częściej twierdzą, że obecny etap zmian na Ukrainie to krok do upadku Ukrainy. Częściej zamierzają w Polsce zostać kobiety niż mężczyźni. Respondenci ci wywodzą się z rodzin ze średnim statusem społeczno-zawodowym. Częściej uważają oni, że obecnie młodzież nie ma na Ukrainie możliwości realizacji swoich planów życiowych. Są to ponadto zwolennicy ukraińskiej integracji europejskiej i wejścia ojczyzny w struktury NATO. Wśród tych respondentów w większym stopniu dostrzegany jest także problem korupcji na Ukrainie.

Wyjechać na Zachód zamierzają respondenci z wyższym statusem społeczno-ekonomicznym. Mają oni trudności w określeniu szans życiowych młodzieży na Ukrainie. Częściej są też pozytywnie nastawieni do integracji europejskiej.

Prowadzone analizy pokazują, że wybór strategii życiowej emigrantów może zależeć od posiadanych zasobów. Osoby pozbawione zasobów ekonomicznych, kulturowych oraz pozytywnie oceniające zmiany na Ukrainie są skłonne powrócić do kraju po studiach. Być może brak zasobów utrudnia im integrację w Polsce, stąd też łatwiejsza decyzja o powrocie. Z kolei średni poziom zasobów skłania studentów do pozostania w Polsce. Pesymistycznie oceniają oni rozwój wydarzeń na Ukrainie i dobrze radzą sobie w Polsce, więc zamierzają tutaj pozostać. Ostatnia strategia, polegająca na wyjeździe z Polski na Zachód, charakteryzuje studentów posiadających zasoby ekonomiczne i kulturowe. Ci studenci będą starać się maksymalizować swoje stopy zwrotu ze studiów na zachodnim rynku pracy. Studia w Polsce pozwoliły na opuszczenie Ukrainy i przygotowanie się do wejścia na zachodni rynek pracy.

Na zakończenie analiz zostanie pokazane jak typ środowiska społecznego różnicuje mechanizmy adaptacji ukraińskich studentów. Wyniki porównań motywów, jakimi kierowali się studenci wybierając studia w Polsce, pokazują kilka różnic.

O tym, że warto jechać do Polski na studia, gdyż jest wyższy poziom nauczania częściej myśleli studenci ukraińscy studiujący w Rzeszowie (52\%), Przemyślu (43\%) niż w Krakowie (22\%). Przyjazd do Polski motywowany występowaniem demokracji i wolności częściej się pojawiał u studentów z Przemyśla (16\%), Rzeszowa (16\%) niż z Krakowa (9\%). Posiadanie europejskiego dyplomu umożliwiającego wyjazd do pracy na Zachodzie mocniej akcentowali studenci z Przemyśla (38\%) i Rzeszowa (48\%) niż Krakowa (24\%). Na to, że wybór uczelni był podyktowany jej bliskim położeniem od domu wskazało w Przemyślu (34\%), w Rzeszowie (39\%), 
w Krakowie (9\%). Częściej też studenci z Przemyśla (37\%), Rzeszowa (49\%) niż z Krakowa (18\%) wskazywali, że po studiach będzie łatwiej znaleźć pracę i zrobić karierę. Na możliwość samorealizacji i rozwój własnych zainteresowań częściej wskazywali studenci z Rzeszowa (45\%), Przemyśla (25\%) niż z Krakowa (15\%). Częściej też w Rzeszowie (29\%) niż w Przemyślu (15\%) i Krakowie (8\%) wskazywano, że motywem emigracji była chęć ucieczki od konfliktu i wojny na Ukrainie. O tym, że łatwiej się usamodzielnić i sprawdzić w nowej sytuacji częściej przekonani byli studenci w Przemyślu (17\%), Rzeszowie (17\%) niż Krakowie (7\%). Na ciekawsze życie towarzyskie, możliwość atrakcyjnego spędzenia czasu wolnego częściej zważali studenci w Rzeszowie (46\%) i Przemyślu (39\%) niż w Krakowie (11\%). Wybór studiów w Polsce ze względu na panującą korupcję na Ukrainie bardziej był widoczny u studentów z Krakowa (34\%) niż Przemyśla (16\%) i Rzeszowa (16\%). Wyniki porównań wskazują, że studenci wybierający uczelnie w Przemyślu i Rzeszowie byli pod wpływem działania czynników przyciągających, a studiujący w Krakowie podlegali czynnikom wypychającym. Być może ci pierwsi częściej wybierali ośrodek akademicki na zasadzie, że wystarczy przekroczyć granicę Ukrainy i już znajdą się w lepszym świecie. Drudzy zaś postanowili pojechać dalej, aby uciec od problemów trawiących społeczeństwo ukraińskie.

Opiniana temat trudnościzwiązanych zpobytem wPolsceróżnicowanabyłatypem ośrodka akademickiego. Na brak pieniędzy, drogie utrzymanie i wysokie koszty życia narzekaliczęściejstudenciw Przemyślu(50\%), Rzeszowie(48\%)niżw Krakowie(32\%). O nieznajomości języka częściej mówili studenci w Krakowie (53\%) niż Rzeszowie (44\%) i Przemyślu (36\%). Trudności ze znalezieniem mieszkania częściej wystąpiły w Krakowie (28\%) niż Rzeszowie (21\%) i Przemyślu (16\%). Tęsknota za znajomymi i rodziną bardziej doskwierała młodzieży w Rzeszowie (47\%), Krakowie (41\%) niż w Przemyślu (28\%). Problem samotności częściej się pojawiał wśród studentów w Krakowie (29\%), Rzeszowie (17\%) niż w Przemyślu (9\%). O tym, że nie było żadnych problemów z przenosinami do Polski najczęściej wspominali studenci z Przemyśla (22\%) niż Rzeszowa (10\%) i Krakowa (11\%). Zaprezentowane analizy wskazują, że młodzież studiująca w Przemyślu głównie narzekała na trudności materialne. W dużym mieście czyli Rzeszowie i Krakowie pojawił się problem ze znajomością języka, znalezieniem mieszkania, tęsknotą za rodziną oraz samotnością. Okazuje się, że małe miasto z małą uczelnią (liczącą około 1000 osób) położone nieopodal granicy z Ukrainą tworzy dobry habitat dla ukraińskiej młodzieży. Wynikać to może z tego, że przemyska uczelnia posiada akademiki, w których głównie zamieszkują studenci z Ukrainy, studiuje w niej sporo osób z Kartą Polaka. Miasto też jest zamieszkiwane przez Ukraińców, część studentów przyjechało na studia z miejscowości położnych nieopodal granicy polsko-ukraińskiej. Wszystkie te czynniki sprawiają, że w mieście na granicy integracja społeczna studentów ukraińskich przebiega najlepiej. Kraków i Rzeszów rządzi się innymi prawami. Badani studenci przyjeżdżają z dalszych zakątków Ukrainy. W większości są to studenci 
płacący za studia bez znajomości języka, bez polskich korzeni. Uczelnie prywatne nie dysponują akademikami, co utrudnia studentom znalezienie odpowiedniego lokum. W środowisku dużych uczelni studenci ukraińscy się separują, przebywają często tylko w swoim towarzystwie. Duża odległość od domu oraz „samotność w tłumie" wywołuje nostalgię za rodziną, przyjaciółmi. W konsekwencji, jak pokazują wyniki analiz, integracja społeczna w dużych miastach na dużych uczelniach jest utrudniona.

Wraz ze zmianą ośrodka akademickiego zmianie ulegały oceny warunków studiowania ${ }^{67}$. Najniżej poziom nauczania został oceniony w Przemyślu $(3,33)$, lepiej w Krakowie (3,70), Rzeszowie $(3,81)$. Obsługa dziekanatów została oceniona najniżej w Przemyślu $(3,58)$, lepiej w Krakowie $(3,77)$ i Rzeszowie $(3,79)$. Życzliwość wykładowców została oceniona słabiej w Przemyślu (3,70), wyżej w Rzeszowie $(3,94)$, Krakowie $(3,99)$. Dostępność do komputerów i Internetu najlepiej ocenili studenci w Rzeszowie $(4,36)$, Krakowie $(4,10)$, gorzej w Przemyślu $(3,68)$. Komunikację miejską najwyżej oceniono w Rzeszowie $(3,86)$, w Krakowie $(3,77)$ i słabiej w Przemyślu $(3,44)$. Kulturalną ofertę miasta najlepiej ocenili studenci w Rzeszowie (3,55), Krakowie (3,39), słabiej w Przemyślu (3,33). Możliwość spędzenia czasu wolnego najlepiej ocenili studenci w Rzeszowie $(3,61)$, w Krakowie $(3,53)$, słabiej w Przemyślu (3,29). Możliwość znalezienia pracy w trakcie studiów najlepiej ocenili studenci w Krakowie $(3,30)$, gorzej w Rzeszowie $(2,94)$ i Przemyślu $(2,62)$. Możliwość znalezienia pracy po studiach lepiej ocenili studenci w Rzeszowie $(3,32)$ i Krakowie $(3,30)$ niż w Przemyślu $(3,04)$. Możliwość realizacji swoich zainteresowań najlepiej ocenili studenci w Rzeszowie $(3,51)$, słabiej w Przemyślu $(3,24)$ i Krakowie $(3,18)$. Życzliwość mieszkańców miasta najlepiej ocenili w Rzeszowie $(3,73)$, słabiej w Krakowie $(3,40)$ i Przemyślu $(3,35)$.

Zebrane obserwacje pokazują, że mała państwowa uczelnia zebrała najniższe noty we wszystkich ocenianych wymiarach. Lepiej wypadła prywatna uczelnia w Rzeszowie, która uchodzi za nowoczesną. Studenci z krakowskich uczelni nieco niżej ocenili warunki studiowania poza możliwością znalezienia pracy w trakcie studiów. Pod tym względem Kraków daje dużo większe możliwości. Duże znaczenie przy ocenie warunków studiowania ma też sam ośrodek akademicki. Przemyśl nie może konkurować tutaj ani pod względem oferty kulturalnej, ani pod względem rynku pracy. Trzeba przyznać, że komunikacja też nie jest mocną stroną grodu nad Sanem. W mieście średniej wielkości jest lepiej, uczelnia prywatna koncentruje się na dbaniu o potrzeby studenta - klienta w większym stopniu niż uczelnie państwowe. Rzeszów ma też te zalety, że nie jest dużym miastem (160 tys.) w związku z tym łatwiej się poruszać i wszystko wydaje się jest na miejscu. Należałoby też rozważyć, na ile na uzyskane oceny ma wpływ propaganda sukcesu prowadzona na prywatnej uczelni, jak też w samym mieście.

${ }^{67}$ Wszystkie wymienione różnice były istotne statystycznie przy poziomie istotności $\alpha \leq 0,05$. 
Zaobserwowano też wpływ środowiska społecznego na ocenę szans na zdobycie pracy po studiach. O tym, że wiedza i umiejętności zdobyte na studiach zwiększą szansę na znalezienie dobrej pracy najbardziej byli przekonani studenci w Krakowie 63\%. Rzadziej ten pogląd wyrażali studenci w Rzeszowie (49\%) i Przemyślu (53\%).

Kontynuować naukę na studiach magisterskich zamierzało 61\% w Przemyślu, 52\% w Krakowie i 37\% w Rzeszowie. Pracować jednocześnie i studiować zamierzało 18\% w Przemyślu, 15\% w Krakowie i 37\% w Rzeszowie. Pójść do pracy najczęściej zamierzali studenci w Krakowie (27\%), rzadziej w Rzeszowie 12\% i Przemyślu 8\%.

Po zakończeniu studiów wrócić na Ukrainę zamierzało w Przemyślu (17\%), w Rzeszowie (10\%) w Krakowie (14\%). Pozostać w Polsce chciało najwięcej studentów studiujących w Krakowie (76\%), w Rzeszowie (43\%), w Przemyślu (54\%). Wyjechać do innego kraju zamierzało w Rzeszowie (47\%), w Przemyślu (30\%), w Krakowie (11\%).

Ostatni wynik pokazuje, że typ ośrodka akademickiego, a konkretnie wielkość miasta i związane z tym szanse, jakie stwarza mają wpływ na życiowe plany. Kraków stanowi metropolię i dzięki temu przyciąga do siebie młodzież studencką. Jak się okazuje, oferuje on najlepsze warunki do rozwoju i życia, dzięki temu może zatrzymywać kapitał ludzki u siebie. Rzeszów i Przemyśl raczej stanowią punkt tranzytowy z Ukrainy do innego miasta w Polsce lub za granicą. Studenci przychodzą studiować powodowani bliskością tych uczelni od miejsca zamieszkania. Jednakże niewielu $\mathrm{z}$ nich na trwale wiąże swoje życiowe plany z tymi miastami.

\section{Uwagi końcowe}

Prowadzone analizy pozwoliły na uzyskanie odpowiedzi na postawione na wstępie pytania. Z zebranych obserwacji wynika, że ukraińska młodzież wyjeżdża na studia do Polski w celu zdobycia europejskiego dyplomu umożliwiającego podjęcie dobrze płatnej pracy, dającej szanse na wysoką jakość życia. Studia w Polsce są traktowane jako inwestycja w edukację, która ma przynieść w przyszłości zysk. Polska jest wybierana jako kraj docelowy, gdyż cieszy się wśród Ukraińców dobrą opinią, a koszty życia i studiowania są niższe od zachodnioeuropejskich. $\mathrm{Na}$ emigrację edukacyjną mają także wpływ tendencje indywidualizacyjne, jakie się pojawiają w społeczeństwie ukraińskim, przechodzącym transformację. Młodzież coraz częściej myśli o realizacji swoich potrzeb, o samorealizacji. Mieszkając w globalnej wiosce, pragnie ona żyć i pracować tak jak młodzież w innych krajach zachodnich. Dlatego też coraz częściej podejmuje decyzję o wyjeździe na studia do Polski. Emigracja edukacyjna jest pierwszym krokiem do emigracji właściwej.

Po przyjeździe do Polski najwięcej problemów przysparzają młodym czynniki ekonomiczne. Studenci z Ukrainy przyjeżdżają z biedniejszego kraju i, jak 
pokazują badania, wśród studentów zagranicznych w Polsce są oni grupą najbiedniejszą studentów, a ich środki na utrzymanie pochodzą $w$ większości od rodziny ${ }^{68}$. W związku z tym nie dziwi fakt, że mogą mieć oni problemy z zabezpieczeniem wszystkich kosztów pobytu. Niekorzystnie na sytuację ekonomiczną wpływa też niska wartość hrywny w stosunku do złotego. Ponadto poza dużymi miastami trudno znaleźć odpowiednią pracę, która pozwoliłby poprawić stan finansów. Zatem czynniki ekonomiczne mogą stanowić największą barierę w integracji w Polsce. Poza nimi pojawiają się także czynniki kulturowe, do których należy zaliczyć brak dostatecznej znajomości języka oraz izolację wobec polskich rówieśników. Być może należy rozpatrywać ten problem kompleksowo. W związku z tym, że studenci z Ukrainy są biedniejsi, mogą także odczuwać wykluczenie towarzyskie. Brak dobrej znajomości polskiego ogranicza możliwości nawiązywania kontaktów z młodymi Polakami, a to prowadzi do separowania się studentów, co automatycznie utrudnia naukę języka i poznanie polskiej kultury. Być może przebywanie wśród swoich daje także poczucie bezpieczeństwa i stanowi zarazem mechanizm obronny przed konsekwencjami szoku kulturowego. Faktem jest, że ten problem jest dostrzegany zarówno w dużych miastach, jak też na Podkarpaciu.

Studenci w trakcie swojego pobytu najlepiej oceniają warunki studiowania na polskich uczelniach. Wyrażają zadowolenie przede wszystkim z nowoczesnej infrastruktury, jaka ich otacza oraz dostępu do nowoczesnych technologii. Na jakość studiów wpływają też stosunki społeczne na polskich uczelniach. Ukraińska młodzież jest pozytywnie zaskoczona podejściem wykładowców i administracji uczelnianej do studenta. Stosunki te są oparte na szacunku, życzliwości, co rodzi zadowolenie, gdyż dotychczasowe doświadczenia młodzieży były zgoła odmienne. Dobre samopoczucie, wynikające ze studiowania w Polsce, psuje jednak trudność ze znalezieniem pracy $\mathrm{w}$ trakcie studiów i po studiach. To właśnie problemy ze znalezieniem zatrudnienia i możliwości dorobienia na własne utrzymanie trzeba uznać za największy problem ukraińskich studentów w Polsce.

Pomimo problemów i trudności, większość studentów zamierza kontynuować naukę na studiach magisterskich. Około jedna trzecia zamierza pracować i edukować się jednocześnie. Studia magisterskie są traktowane jako lepsze wykształcenie, które podnosi szanse na uzyskanie dobrej pracy. Młodzi Ukraińcy nie chcą wracać po studiach do swojego kraju. Ponad połowa planuje pozostać w Polsce, a jedna trzecia wyjechać dalej na Zachód. Negatywna ocena sytuacji gospodarczej i politycznej na Ukrainie, niższy poziom życia sprawiają, że młodzież nie zamierza wracać. Swoją przyszłość widzi poza Ukrainą, dlatego też wybierają zagraniczne studia pozwalające na przygotowanie się do życia na obczyźnie.

Warto też podkreślić, że wartością dodaną niniejszego artykułu jest ukazanie wpływu wielkości ośrodka akademickiego na proces integracji społecznej

${ }^{68}$ Ibidem. 
studentów. Małe ośrodki w pobliżu granicy z Ukrainą przyciągają studentów mniej zasobnych, najczęściej z polskimi korzeniami, chcących uzyskać dyplom mający zwiększyć szanse życiowe. W średnich miastach mogą pojawiać się studenci traktujący edukację w Polsce jako narzędzie pomocne w wydostaniu się na zachód. Zaś duże ośrodki akademickie zlokalizowane w metropoliach stanowią punkt docelowy migrantów edukacyjnych. Oferują wysoką jakość życia, atrakcyjne rynki pracy i możliwość realizacji dążeń związanych ze szczęściem rodzinnym, karierą. Można założyć, że na trajektorie imigracyjne mają wpływ cechy osobowości społecznej i posiadane jednostkowe zasoby. Powyższe założenia warto poddać weryfikacji w kolejnych badaniach o mieszanym charakterze.

\section{Bibliografia}

Beck U. (2002), Społeczeństwo ryzyka, Warszawa: Scholar.

Becker G.S. (1962), Investment in Human Capital: A Theoretical Analysis, „Journal of Political Economy", Vol. 70, 9-49.

Bhandari R., Blumenthal P. (eds.) (2010), International students and global mobility in higher education: National trends and new directions, New York: Palgrave Macmillan US.

Bierówka J. (2016), Opinie studentów ukraińskich na temat ich integracji akademickiej, „Państwo i Społeczeństwo", Vol. 16, Issue 1, 199-217.

Bilyakovska O. (2011), Ukrainian Student Migration to Poland, „Humanities \& Social Sciences” Vol. 1, 292-293.

Bosma U., Lucassen J., Oostindie G. (eds.) (2012), Postcolonial Migrants and Identity Politics: Europe, Russia, Japan and the United States in Comparison, New York and Oxford: Berghahn Books.

Brunarska Z. (2013), Współczesne migracje na obszarze poradzieckim przez pryzmat koncepcji migracji poimperialnych, „Central and Eastern European Migration Review”, Vol. 2, Issue 2, 39-54.

Cherba V., Tobol H., Mushkatiorova D. (2017), The Reasons of Educational Migrations of Ukrainian Students Abroad, „Інвестиції: практика та досвід”, Vol. 12, 68-72.

Choudaha R. (2017), Three waves of international student mobility (1999-2020), „Studies in Higher Education", Vol. 42, Issue 5, 825-832.

Choudaha R., Chang L. (2012), Trends in international student mobility, „World Education News \& Reviews", Vol. 25, Issue 2, 1-5.

Collins R. (1979), The Credential Society, New York: Academic Press.c

J. Czapiński, T. Panek (red.) (2015), Diagnoza spoteczna 2015, Warszawa: Rada Monitoringu Społecznego.

Długosz P. (2015), Zjawisko edukacji transgranicznej na przykładzie ukraińskich studentów na Podkarpaciu, „Youth Policy: Problems and Prospects”, Vol. 6, 161-168.

Drucker P.F. (1999), Społeczeństwo prokapitalistyczne, Warszawa: Wydawnictwo Naukowe PWN.

Findlay A.M., King R., Smith F.M., Geddes A., Skeldon R. (2012), World class? An investigation of globalisation, difference and international student mobility, „Transactions of the Institute of British Geographers", Vol. 37, Issue 1, 118-131.

Gomółka K. (2015), Students from Ukraine, Belarus and Moldova at Polish universities, „Annales Universitatis Mariae Curie-Skłodowska, sectio K - Politologia”, Vol. 22, Issue 1, 213-225.

Gońda M. (2017), Mobilność edukacyjna w sytuacji migracji do korzeni: polska diaspora na studiach w kraju przodków, „Studia Migracyjne - Przegląd Polonijny”, Vol.1, 229-258. 
Guruz K. (2011), Higher education and international student mobility in the global knowledge econo$m y$, New York: State University of New York Press.

Hrynkevych O. (2017), Cross-border factor of educational migration of Ukrainian youth to Poland: social-economic opportunities and threats, „Economic Annals-XXI”, Vol. 163, Issue 1, 26-30.

Inglot-Brzęk E., Stopa M. (2015), Nowe konteksty „starych” pograniczy. Przypadki ukraińskich studentów w rzeszowskiej uczelni, w: Chudzik, A. (red.), Na pograniczach. Kulturowe obrazy ludzi i miejsc, Sanok: Wydawnictwo PWSZ, s. 229-246.

Izdebska-Długosz D. (2017), Dlaczego Polska? Motywy wyboru studiów w Polsce u młodzieży ukraińskiej - perspektywa porównawcza, w: Kordoński, R., Kordońska, O., Muszyński, Ł., (red.), Doświadczenia oraz perspektywy strategicznego partnerstwa, t. 2, Lwów-Olsztyn: Wydawnictwo Uniwersytetu Lwowskiego, s. 63-75.

Jóźwiak I., Piechowska M. (2017), Crisis-driven Mobility between Ukraine and Poland. What Does the Available Data (Not) Tell Us, „CMR Working Papers”, Vol. 99, 1-26.

Kapera S. (2017), Motywy wyboru i oczekiwania studentów z Ukrainy wobec kształcenia na kierunkach związanych z turystyką, „Turyzm”, Vol. 27, Issue 1, 19-23.

Mazzarol T., Soutar N.G. (2002), „Push-pull” factors influencing international student destination choice, „International Journal of Educational Management”, Vol.16, Issue 2, 82-90.

Mincer J. (1974), Schooling, Experience and Earnings. National Bureau of Economic Research, New York: Columbia University Press.

Pakosz M. (2017), Rekrutacja kandydatów z Ukrainy na studia wyższe w Polsce. Perspektywa dla polskich uczelni, w: Siwińska B., Mazurek G. (red.), Czas internalizacji II, Warszawa: Elipsa, s. $202-218$.

Pietraś M. (2017), Umiędzynarodowienie szkolnictwa wyższego w Polsce, w: Domański T., Stępień-Kuczyńska A., Włodarska-Frykowska A. (red.), Internacjonalizacja polskich ośrodków politologicznych, Łódź: Wydawnictwo Uniwersytetu Łódzkiego, s. 81-95.

Rickett R. (1991), International Student Mobility, „Higher Education in Europe”, Vol. 2, Issue 4-5, 37-40.

Rodchenko V.B., Rekun G.P., Prus Y.I. (2017), External academic mobility of students: case for Ukraine, „Handel Wewnętrzny”, Vol. 336, Issue 1, 56-68.

Semiv L., Hvozdovych Y. (2012), The intellectual migration of the youth in Ukraine: the backgrounds for „brain circulation”, „Journal of International Studies”, Vol. 5, Issue 2, $72-81$.

Siwiński W. (2017), Autostrada edukacyjna Polska-Ukraina - projekt w budowie 2017, upc.kpi.ua/documents/dni_nauky/presentations/06-04-2017/Siwinski.pdf, dostęp: 10.10.2017.

Stasik A. (2017), Raport z badania ankietowego „Zagraniczni studenci 2015/16”, https://nawa.gov.pl/ nawa/raporty-i-analizy, dostęp: 22.11.2017.

Studenci zagraniczni w Polsce w 2015, (2015), Warszawa, http://www.studyinpoland.pl/ Szkoly wyzsze $i$ ich finanse w 2016 r., http://stat.gov.pl/obszary-tematyczne/edukacja/edukacja/szkoly-wyzsze-i-ich-finanse-w-2016-r-,2,13.html, dostęp: 22.10.2017.

Verbik L., Lasanowski V. (2007), International student mobility: Patterns and trends, The Observatory on Borderless Higher Education Woburn House, London, http://www.obhe.ac.uk/documents/ view_details?id=14, dostęp: 5.11.2017.

Wallerstein I. (2011), The modern world-system I: Capitalist agriculture and the origins of the European world-economy in the sixteenth century, with a new prologue, San Francisco: University of California Press.

Żołędowski C. (2010), Studenci zagraniczni w Polsce, Warszawa: Wydawnictwo UW.

Бондарук Л. М., Щерба Л.М. (2017), Роль міжкультурної освіти у процесі інтеграції України в європейський простір, „Педагогічний пошук”, Vol. 94, Issue 2, 32-35. 
Зарембо К. (2017), Молодь України 2017. http://neweurope.org.ua/analytics/ukrayinske-pokolinnya-z-tsinnosti-ta-oriyentyry, dostęp: 22.11.2017.

Ключковська І., Марусик Ю, П’ятковська О. (2014), Звіт про результати дослідження міграційних настроїв студентів Львова, Львів. http://miok.lviv.ua/wp-content/uploads/2015/04/ zvitpj.pdf, dostęp 20.11.2017.

Козієвська О. (2013), Академічна мобільність: причини вибору навчання за кордоном, „Вища освіта України”,Vol.1, 88-97.

Слободян О., Стадний Є. (2016), Українськ студенти за кордоном, CEDOS, https://cedos.org.ua/ uk/osvita/ukrainski-studenty-za-kordonom-skilky-ta-chomu, dostep: 10.10.2017.

Стадний Є. (2015), Українські студенти в польських ВН3 (2008-2015), CEDOS, https://cedos. org.ua/uk/osvita/ukrainski-studenty-v-polskykh-vnz-2008, dostęp:11.10.2017. 